\title{
Bacterial Beta-lactamase Measurement
}

National Cancer Institute

\section{Source}

National Cancer Institute. Bacterial Beta-lactamase Measurement. NCI Thesaurus. Code C161400.

The determination of the amount of bacterial Beta-lactamase present in a sample. 